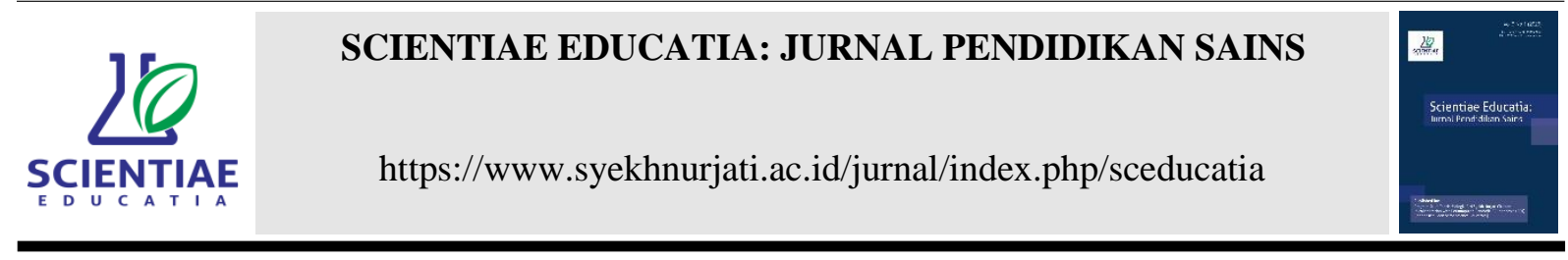

\title{
Development of the Religious Values Model to Improve Learning Outcomes of the Digestive System Subject
}

\author{
Nurika*, Edy Chandra, Asep Mulyani
}

Department of Biology Education,Faculty of Teacher Training and Education, IAIN Syekh Nurjati Cirebon, Indonesia

*Corresponding author: J1 Perjuangan By Pass Sunyaragi Kesambi Kota Cirebon, Jawa Barat, Indonesia. E-mail addresses: nurikakusba@gmail.com

\begin{tabular}{|c|c|}
\hline article info & $a b s t r a c t$ \\
\hline $\begin{array}{l}\text { Article history: } \\
\text { Received: } 03 \text { January } 2021 \\
\text { Received in revised form: } 09 \\
\text { April } 2021 \\
\text { Accepted: } 20 \text { June } 2021 \\
\text { Available online: } 30 \text { June } 2021 \\
\text { Keywords: } \\
\text { Digestive system } \\
\text { Learning model } \\
\text { Learning outcomes } \\
\text { Religious value }\end{array}$ & $\begin{array}{l}\text { Islamic education values are crucially applied in learning biology } \\
\text { because its topics are conceptual and contextual. Thus, biology class } \\
\text { must prioritize the learning values. Teachers can use each design } \\
\text { containing to develop learning activities. The values model is a } \\
\text { learning model prioritizing the application of life values. This study } \\
\text { aimed to examine the students' activities in the experimental class, } \\
\text { examine different learning outcomes between students applying the } \\
\text { religious-based values learning model and students applying } \\
\text { conventional learning models, and examine students' attitudes } \\
\text { towards biology learning applying the values learning model. This } \\
\text { research employed the development research design and test one } \\
\text { experimental class in the broad test. The experimental and control } \\
\text { classes with a purposive sampling technique were employed in the } \\
\text { pretest-posttest control group research design. The data were } \\
\text { collected using observation, tests, and questionnaires of attitude } \\
\text { values. The data were analyzed using the SPSS V.21 Software. The } \\
\text { results showed that student learning activities increased in each test. } \\
\text { The N-Gain value signified that the experimental class had higher } \\
\text { learning outcomes than the control class. In addition, the learning } \\
\text { outcomes in each test increased. The experimental class of students } \\
\text { who applied biology with the religious-based values model in each } \\
\text { meeting increased. The experimental class had higher learning } \\
\text { outcomes than the control class. The average posttest score of } \\
\text { student attitude in the experimental class was } 87.59 \text {, while in the } \\
\text { control class was } 81.38 \text {. Meanwhile, the experimental class had the } \\
\text { average posttest score of the implementation test was } 80.37 \text {, and the } \\
\text { posttest control class was } 79.44 \text {. The development of religious values } \\
\text { models can improve student learning outcomes. } \\
\text { 2021 Scientiae Educatia: Jurnal Pendidikan Sains }\end{array}$ \\
\hline
\end{tabular}

\section{Introduction}

Madjid (2014) states that education must refer to religion-based education. The National Education Goals of Law Number 20 of 2003, concerning the development of students' potentials, to become human beings who believe and are devoted to God Almighty, have noble characters, are healthy, knowledgeable, capable, creative, and independent, and become good citizens. Democracy, responsibility, and the importance of education, especially character education reflecting values of God in its actualization, must be implemented and applied in every 
educational sector. Value-based education helps students more significantly appreciate and reflect religious values in learning.

The students' successful learning that increases faith and piety is strongly influenced by students' internal conditions and external factors. One of the external factors influencing students' success in understanding a learning topic is the teacher's ability to choose the right learning methods and media. Therefore, the values of faith and piety can color the learning. The authors integrated the values of faith and piety into the subject matter, especially biology subjects, by using teaching materials teaching faith and piety sourced from the Qur'an and hadith. These materials were composed by the teachers. The Qur'an is the Islamic holy book and a source of knowledge because its verses are the words of Allah Almighty, the one who created this universe. The word of God was conveyed by the Prophet Muhammad Peace Be Upon You, a holy man who has the title of Al-Amin (trusted).

The formulation of the national education goals bases the development of the cultural values of the national characters. Other values agreeing with the goals of national education are the dimensions of faith and piety and noble characters. They are integrated parts of the national education goals. This statement indicates that creating people with characters, love, peace, honesty, responsibility, and good morals is the duty of all parties, not only certain fields of study or activities. Thus, education as an integrated system must be systematically directed to form human beings with characters. Based on this explanation, character education should be integrated into learning in every subject and is necessarily developed, made explicit, and linked to the daily context (Fitri, 2010).

Islam is a religion that is Rahmatan Lil Alamin (A mercy to all creation). This condition is proven in the Al-Qur'an, a collection of the words of Allah Almighty which was conveyed to the Prophet Muhammad SAW as a guide and way of life for people (Lubis, 2011). The Qur'an talks a lot about how humans have a good relationship with their Lord, fellow creatures, and natural surroundings. This explanation indicates that Islam is not only an absolute religion for humans and God, but also for all creatures. Islam and science have become the main topics in international science forums because it discusses a lot about scientific facts previously stated in the Qur'an and Hadith 14 centuries ago (Zain, 2017). Therefore, it is very necessary to learn science integrated with religious values. In the learning process, Islamic-based learning and an appropriate learning model are needed.

The biology material selected to integrate with Islamic values was the digestive system. The digestive system is closely related to food consumed by humans to maintain life. Islam discussed food and eating etiquette in detail. Moreover, the Quran mentions halal (permissible) and haram (forbidden) food. Adab (etiquette) when eating is also discussed in several Hadith and books of the Salaf, one of which is the book of Riyadhus Sholihin by Imam Abu Zakariya Yahya bin Syaraf An-Nawawi Ad-Dimayqy (631-676 H) in Dib al Bugha (2012). This condition can be related to the biology learning process regarding the development of model values based on faith and piety in the food digestive systems of sub-concept material.

Einstein said, "Science without religion is lame, religion without science is blind" (Sidik, 2016). This illustrates the importance of harmony between science and religion. The national curriculum reflected the cultivation of moral values and systems in the core competencies developed by teachers to form students' good characters. These competencies are reflected in core competencies one and two, consist of; 1) Living and practicing the teachings of their religion, 2) Living and practicing honest behavior, discipline, responsibility, caring, cooperation, cooperation, tolerance, peace, courtesy, responsiveness, proactiveness, attitude as a solution for various problems, effective interaction with the social and natural environment, and a selfreflection of the nation associated with the world. 
Core Competence one reflects religious or spiritual values vertically or relates to the obedience of a servant to the creator. Islam considers this concept as Hablumminalloh (spiritual attitude). Meanwhile, core competence two is related to religious values horizontally and human beings (hablumminannas) or shows social attitudes. The word value in the Kamus Besar Indonesian means "price". The price in this case refers to something good and agrees with human life concepts (Amri, 2017). Islamic values mean a set of guidelines, rules, governance, policies, and elements based on Islamic law in their outputs as a reference for behavior, such as thoughts, words, and actions, in a particular object, (Mawardi, 2012).

Prasetyo (2013) states that the nature of science is a way of thinking, a way of investigating, and a collection of knowledge. As a way of thinking, science is a mental activity (thinking) of people who are involved in the investigated field. Scientists try to uncover, explain, and describe natural phenomena. The ideas and explanations of a natural phenomenon are arranged in the mind. This mental activity is driven by curiosity to understand natural phenomena to investigate and review approaches to construct knowledge. Observation and prediction are the basis of methods to solve knowledge problems.

The description of the existing problems shows that teachers necessarily use a learning approach during the teaching process. Thus, the learning is implemented well and easily understood by students. The teaching process denotes that the learning approach can affect student learning outcomes. There are many available learning approaches, and the researchers developed biology learning on the subject of the digestive systems considering faith and piety in three schools. This research examined how this approach affected learning outcomes. Based on the problems above, the researchers compiled a study entitled: development of faith and pietybased values model to improve student learning outcomes of the digestive system subject in class XI science."

\section{Method}

This research is employed a quantitative approach as well as a research and development design developed by Sukmadinata, et al. (2011). These steps included 1) preliminary study, 2) model development (limited and wider trial), and 3) model test (product test and result outreach). This study employed the pretest-posttest control group design, and the method used was the true experimental design method. The researchers in this case could control all external variables that affect the course of the experiment by grouping them into two groups: the experimental and control groups. An experimental group is a group that receives the research treatment. In contrast, the control group is the group that does not receive treatment. The research sample was selected randomly. The following is the design technique of the pretest-posttest control group.

Table 1. Research design in a limited trial

$\begin{array}{lll}\text { Groups } & \text { Treatment } & \text { Posttest }\end{array}$

E $\quad \mathrm{X} \quad \mathrm{O}$

Description: $\mathrm{E}=$ Experimental group; $\mathrm{O}=$ Posttest; $\mathrm{X}=$ Treatment in the experiment class

Table 2. Research design in the extensive trial

\begin{tabular}{cccc}
\hline Groups & Pretest & Treatment & Posttest \\
\hline $\mathrm{E}$ & $\mathrm{O}_{1}$ & $\mathrm{X}$ & $\mathrm{O}_{2}$ \\
$\mathrm{~K}$ & $\mathrm{O}_{1}$ & & $\mathrm{O}_{2}$ \\
\hline
\end{tabular}

Description: $\mathrm{E}=$ Experimental group; $\mathrm{K}=$ Control group; $\mathrm{O}_{1}=$ Pretest; $\mathrm{O}_{2}=$ Posttest; $\mathrm{X}=$ Experiment class treatment 
Table 3. Research Design on the implementation of test

\begin{tabular}{cccc}
\hline Group & Pretest & Treatment & Posttest \\
\hline $\mathrm{E}$ & $\mathrm{O}_{1}$ & $\mathrm{X}$ & $\mathrm{O}_{2}$ \\
$\mathrm{~K}$ & $\mathrm{O}_{1}$ & & $\mathrm{O}_{2}$
\end{tabular}

Description: $\mathrm{E}=$ Experimental group; $\mathrm{K}=$ Control group; $\mathrm{O}_{1}=$ Pretest; $\mathrm{O}_{2}=$ Posttest $\mathrm{X}=$ Treatment in the experiment class

This study used two different classes for the area and implementation tests; they were the experimental and control classes. Therefore, they received different treatment. The experimental class received biology learning integrated with the values of faith and piety and using the values learning model. Meanwhile, the control class only received the biology learning and used the conventional learning model without being integrated with the values of faith and piety and the values learning model. The limited trial only conducted the posttest. Meanwhile, in the broad and implementation trial, the two classes initially received a pretest to measure students' prior knowledge after the learning was completed.

\section{Result and Discussion}

The results and discussion are written in one unit; the author is not justified based on the results and prior discussion in the form of a new chapter. How to write in the results and discussion is done directly by reviewing directly one by one, the research results obtained with relevant references and prioritizing from primary sources. The results of the study can be equipped with tables, pictures, and graphics to clarify the presentation of the research results verbally.

\section{Student learning outcomes in classes implemented by faith and piety based on values learning model in the MA Islamic Center using the limited trial}

In this limited trial, the questions were tested in Islamic high school the MA Islamic Center. Based on this, the researcher gave 50 multiple-choice questions. The questions were then tested and analyzed using the Anates software application to gain validity, significance, distinguished power, and level of difficulty. If the items were declared significant, the questions were possibly delivered to students for extensive testing.

Table 4. Recapitulation of the item analysis

\begin{tabular}{ccccccc}
\hline \multirow{2}{*}{$\begin{array}{c}\text { Standard } \\
\text { Intersection }\end{array}$} & \multirow{2}{*}{$\begin{array}{c}\text { XY. } \\
\text { Correlation }\end{array}$} & $\begin{array}{c}\text { Reliability } \\
\text { Test }\end{array}$ & \multicolumn{3}{c}{ Difficulty Levels } & Very easy \\
\cline { 4 - 6 } & & Moderate & Hard & Significance \\
\hline 6.33 & 0.64 & 0.78 & $30 \%$ & $40 \%$ & $30 \%$ & $66.7 \%$ \\
\hline
\end{tabular}

The limited test showed that the reliability value of the questions was $0.78 \%$, and 50 samples had a moderate level of difficulty. Moreover, of 50 questions, 30 had a significant value. In other words, 30 questions were valid. They were feasibly delivered to students in the broad and implementation tests for pretest and posttest questions in the experimental and control classes. 


\section{Significant learning differences between faith-based biology learning and faith and taqwa- based-biology with the values model in the sub-concept of digestive system discussion}

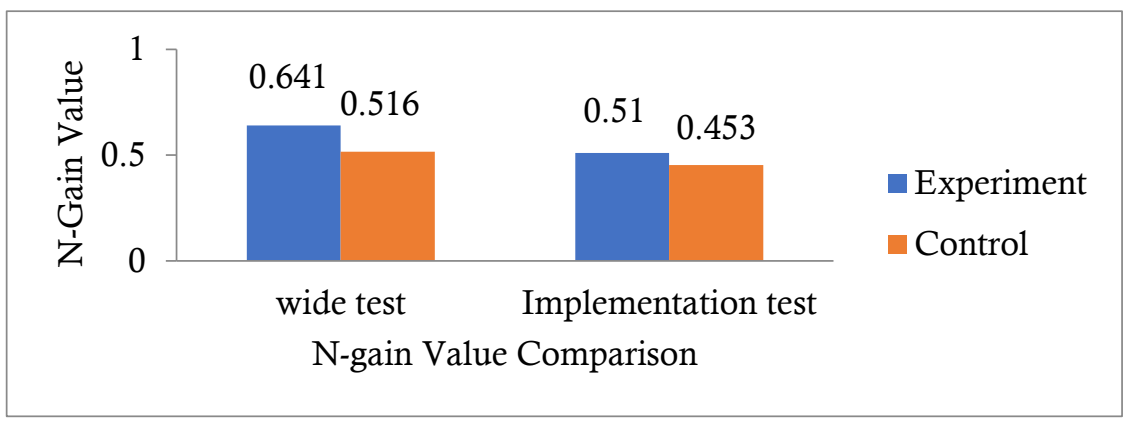

Figure 1. Comparison between the $\mathrm{N}$-gain area test and the implementation test.

Figure 1 shows that the average N-Gain value of student learning outcomes in the experiment and control classes was in the area and implementation tests. Moreover, the graph denotes that the N-Gain value of the experimental class $(0.641)$ in the broad test is greater than the control class (0.516). The wide test proved that the experimental class had a bigger value than the control class. Meanwhile, the implementation test revealed that the score of the experimental class was 0.51 while the control class was 0.45 . This proved that the experimental class was bigger than the control class both in the broad test and in the implementation test.

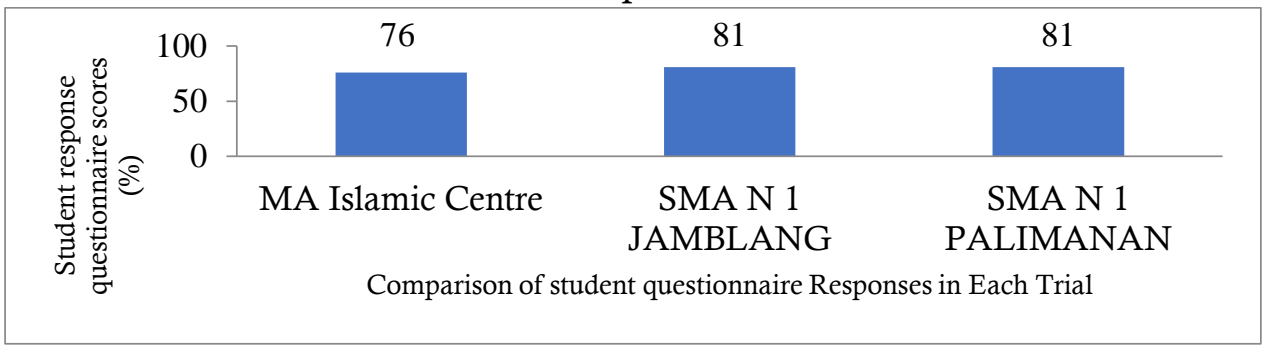

Figure 2. The percentage of comparison of experimental class student questionnaires

Figure 1.2discovered the average questionnaire response of students in the experimental class in each test. The figure shows that $76 \%$ of MA Islamic Center students agreed with the learning outcomes of biology applying the values model based on faith and piety and discussing the subconcept of food digestive systems. The extensive test in the experimental class discovered that $81 \%$ of the tested product increased. Meanwhile, the third implementation or school test in the experimental class denoted that the average score of student response to the questionnaire was $81 \%$. These findings showed that the students in the experimental class and each test agreed to learn biology using the faith and piety-based values model. The data of learning activities of the experimental class students who applied the faith and piety-based values model of biology learning in each trial is presented in the following graph. 


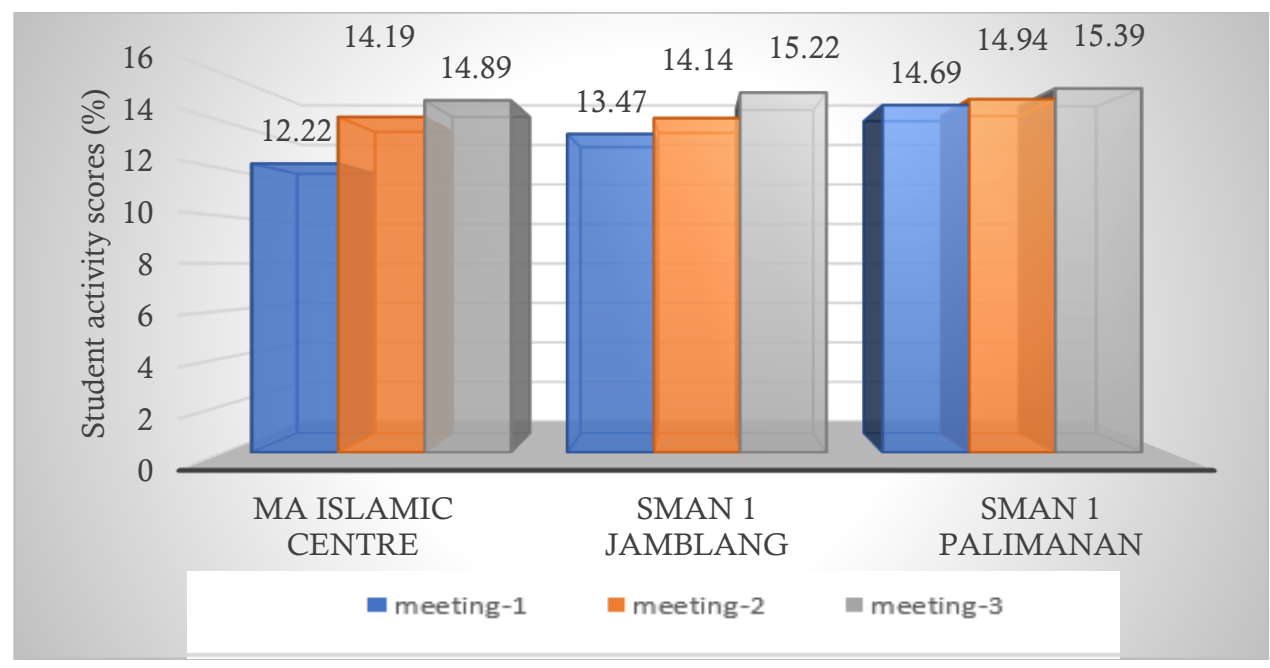

Figure 3. The average percentage of student activities in each meeting and trial

Figure 3 presents the average percentage of students' activities in the experimental class in each trial. The figure shows that students' learning activities increased in each meeting. The observations in the MA Islamic Center revealed that the first meeting had the lowest learning activities among the second and third meetings. the first meeting had a percentage of $12.22 \%$. The score increased to $14.19 \%$ in the second meeting. Meanwhile, the third meeting had a percentage of $14.89 \%$. the obtained data denoted that students' activities increased in each meeting.

The results of the limited and area tests exhibited that students' learning activities increased in each meeting: the first meeting by $13.47 \%$, the second meeting by $14.14 \%$, and the third meeting by $15.22 \%$. This finding also proved that the results of the broad test in each meeting increased the learning outcomes. Figure 1.3 shows the product test and the broad test increased the results' learning outcomes. This indicates that the faith and piety-based values model learning discussing food digestion systems improved student learning outcomes in each meeting. Meanwhile, the implementation test in three schools revealed that learning outcomes were more improved from the product test and test. Figure 1.3 showed that the implementation test in SMAN 1 Palimanan (a public senior high school) increased students' learning activities in all meetings. The first meeting obtained $14.69 \%$, the second meeting gained $14.94 \%$, and the third meeting increased up to $15.39 \%$. To conclude, the implementation test had the highest result.

Based on the preliminary study results, the researchers conducted a draft to develop a syllabus, lesson plans, modules, and questions. The authors initially conducted several analyses that linked the material to the food digestive systems. The analysis included module requirements and characteristics of faith and piety-based material. After validating the product design using an expert assessment, the authors revised the faith and piety-based learning draft by considering inputs from material experts. For example, keywords should be placed on pages directly related to the material., the next stage after revising the product design was an extensive test and Imtaqbased implementation trials. The trial was conducted to determine the effectiveness of the draft and student learning outcomes in the sub-topic of food digestive systems. The first test was the limited test and was conducted at the MA Islamic Center. The test aimed to find out valid questions. Then, the valid questions were tested in the broad and implementation tests.

The research results show that the biology learning process using the faith and piety-based values model discussing the food digestive system was run smoothly following the plan. The researchers examined (1) students' learning activities applying the faith and piety-based values learning model, (2) the effectiveness of the faith and piety-based values learning model on 
students' learning outcomes, and (3) students' attitudes applied to the faith and piety-based values model.

The results of the increasing percentage of students' attitudes were corroborated by Anggraeni (2017), Budur (2013), Lestari (2016), and Ulfa (2016), who discovered that students' activities increased in each meeting. The results of this research agreed with several relevant studies. In other words, the Islamic values-based approach could increase students' activity. Attitude is a tendency to act and can limit or facilitate students to apply their skills and knowledge. They will not understand a concept if they do not willingly do so.

\section{The quran-based biology learning}

Biology is a vehicle to increase knowledge, skills, attitudes, and values create responsibility for the environment, society, nation, state, and belief as well as fear of the God Almighty. Biology concerns with systematic finding, comprehension, the universe, and life. Thus, religious and biological material has a strong relationship, and when they are integrated, they will produce meaningful learning (Nurasni, Darmawati, \& Yustini, 2015). Biological facts, procedures, and phenomena are related to god's creatures, living things, and their lives. Studying biology is expected to make students increasingly glorify the greatness of God.

The Quran is derived from Arabic, from the verb qara'a - yaqra'u - qur'anan, which means reading or repeated reading (Iryani, 2017). Al-Quran is the most perfect reading book. The Quran is also called Al-Fur'qan which means a book that distinguishes legal from unlawful things, good from bad things, commands from prohibitions to abandon. Another name for the Quran is AdDhikr or a book to always remember human's Lord, His commands, and His prohibitions. Kamus Besar Indonesia defines hadith as words, deeds, and takrir (decrees) of the Prophet Muhammad. The hadith was narrated by the prophet or his friends to explain and determine Islamic law (Badan Pengembangan dan Pembinaan Bahasa of the Ministry of Education and Culture, 2016). As the holy book of Islam, the Quran also examines science, including biological science. Many Quran verses explain biological phenomena used as references to assess biology learning. In addition to the Qur'an, Hadith is a source of Islam that discusses biology. Qur'an and Hadith can be studied and linked to biology subjects process to take Islamic values. Therefore, students can have more faith and fear of God Almighty and noble characters that are in accordance with the goals of national education. Many Quran verses explain biological phenomena and can be used as references to assess the subject of biology. In addition to the Quran, Hadith is a source of Islam and discusses a lot of biology. The Quran and Hadith can be studied and linked to the biology learning process to take Islamic values. Thus, students can have more faith and fear of God Almighty and have noble characters as expected by the goals of national education. Many Quran verses explain biology phenomena and can be used as a reference to assess the subject of biology. In addition to the Qur'an, Hadith is a source of Islam and discusses a lot of biology. The Quran and Hadith can be studied and linked to the subject in the biology learning process to take Islamic values. Therefore, students can have more faith, fear of God Almighty, and noble character as expected by the goals of national education.

\section{The role of the quran and hadith in the development of Islamic values}

Value is something that gives meaning to life, provides a reference, and starts points and purposes in life. Moreover, value is an upheld thing, and it can color and animate one's actions. Values are more than just beliefs and always involve patterns of thought and action; thus, there is a very close relationship between values and ethics (Steeman in Adisusilo, 2013). Values are the standards of conduct and attitudes that determine who we are, how we live, and how we treat 
others. Good values can make people better, provide a better life, and treat others better (Linda \& Richard Eyre in Adisusilo, 2013).

Ogunbado and Al-Otaibi (2013), state that Islamic values are principles and based on the Quran and the Sunnah of the Prophet and relevant to Islamic literature to achieve religious qualities. Islamic value is a principle that is believed to be true and based on the Quran, Sunnah, and Ijtihad; it is in the form of aqidah and moral values that are used as guidelines in life (Susilowati, 2017). The Quran guides not only certain people in a certain period but also a universe in all times. The Quran always exists in every age and place. Its guidance is as broad as the breadth of mankind and covers all aspects of life. the Quran directly extracted Islamic sciences, such as the science of interpretation, fiqh, and monotheism,

The importance of integrating Islamic values from the Quran and Hadith to learn science, such as biology, and create a normative framework to formulate educational goals, as stated by Ali and Luluk in Muspiroh (2014). They argue that inculcating Islamic values has several objectives, namely: 1) Developing deeper spiritual insight and a rational understanding of Islam in the context of life, especially related to the verses of kauniyah (nature), 2) Equipping students with various natural knowledge abilities, 3) Developing students' ability to appreciate and justify the comparative superiority of the Islamic knowledge treasures over all other knowledge treasures, 4) Improving emotional impulses through imaginative experiences to enable creative abilities to develop and function and students to know the right and wrong Islamic norms , 5) Helping growing children to learn, and think logically, and guide their thought processes based on hypotheses and concepts of natural knowledge.

Education has a very vital role in the development of the quality of human resources. The quality of human resources can be seen from good morals. Building good morals and character can be done through the education process in schools although it must also be supported by education in the family and community. Moreover, good morals in schools can be developed by inculcating the values of faith and piety (religious) through the learning process (Suryaningsih, 2018). In the concept of Islamic education, Hadith is a philosophical foundation in the systematic development of Islamic education, especially in the Hadith, which more emphasizes morals and education (Jamila, 2016).

Maulana (2015) proposes a meaningful approach: "Efforts in research activities aim to establish relationships of the investigated subjects or methods to understand and clarify research problems as well as clarify, explain, and return to the truth. The educational approach is a response or a point of view that becomes the basis or source to create learning values; thus, learning can be established properly and correctly and follows the objectives of the national education.

\section{Integrating the Quran and hadith in biology learning to develop students' Islamic values}

The digestive system refers to a system that processes food and absorbs nutrients needed by the body. This system will break down complex food molecules into simple ones with the help of enzymes; thus, they are easily digested by the body. The digestive system processes food to enable the body cells to absorb and use it physically and chemically. The digestive system consists of the digestive tract (alimentary) with muscular tubes that extend from the mouth to the anus and involves accessory organs, such as teeth, tongue, salivary glands, liver, gallbladder, and pancreas. The digestive tract located below the diaphragm area is called the gastrointestinal tract.

The Qur'an explains that humans should eat and drink according to the teachings of the prophets and apostles. As mentioned in Surah al-Baqarah verse 172 which reads "O you who believe, Eat of the lawful and clean things that We have provided you with, and be grateful to Allah, if it is indeed He Whom you serve (to Whom you became servants)." There are several 
benefits of integrating biology learning into learning the Quran and Hadith. Jelen and Lockett (2014) reveal that religious variables, including religious views and scriptures, are closely and significantly related to changes in students' attitudes for the better. Integrating religious values into the learning curriculum produces good human beings to apply knowledge and skills in accordance with Islam (Jamilah et al., 2014; Mufid, 2014). The introduction and comprehension of the Quran verses and Hadith related to biology are expected to provide benefits and functions.

According to Marvavilha (2018), integrating Islamic values from the Qoran or Hadith into science learning activities, especially biology in bayani, burhani, and irfani ways. The integration of the bayani context seeks to clarify, reveal, and express the meaning of the conversation considering lafadz. The main characteristic is using the text as the main source of knowledge. In this case, the text referred to the Quran verses. Many verses explain science, and in this case, science and religion aimed to be lead humans to more glorify Allah SWT.

Batubara (2018) asserts that science, particularly biology, can be integrated with Islam through the Quran and Hadith, through several strategies; 1) Using the Quran and Hadith as a source of knowledge, 2) Expanding the study material of Islam and avoiding dichotomy of science, 3) Nurturing ka person with ulul albab characters, 4) Tracing the Quran verses about science, 4) Developing an educational curriculum

Islam should contain extraordinary natural wonders and their orderly, neat, and harmonious laws. Biology plays an important role in producing various technologies and products and acts as a medium of recognition and human contemplation of God. Commands to meditate and reflect God's creation in the heavens and on earth are found and commanded in the Quran and Hadith (Rahman, 2011). Thus, integrating the Quran and Hadith into biology learning is necessary to foster religious (Islamic) values for students to achieve national education goals.

\section{Conclusion}

The Quran and Hadith can be used as sources to build students' Islamic values in learning biology. The integration of the Quran and Hadith in the biology learning process enables students to understand biological concepts and develop Islamic values. Thus, they become better and pious human beings who believe and have noble characters as expected by the goals of national education. The Quran and Hadith can be integrated into biology learning by recording and analyzing the Quran verses and Hadith implicitly or explicitly following with the biology. Integrating the Quran verses and Hadith into the biology learning process was done by selecting appropriate learning models. The experimental class students who applied biology learning with the faith and piety-based values model showed an increase in learning activities in each meeting. The limited test showed that the highest increase occurred in the third meeting. Meanwhile, the area test and the implementation test showed that the learning outcomes increased in the third meeting. These results were seen from the average learning activities in each meeting. Finally, the experimental class showed higher learning outcomes than the control class.

\section{References}

Adisusilo, S. (2013). Learning the Value of Character Construction and VCT as an Innovation of Affective Learning Approach. PT Rajagrafindo Persada.

Amiri, M. N. et. al (2017). Integration of Islamic Values in Biology Learning at Al-Ulum Terpadu Islamic High School Medan. Journal of Edu Religion, 1(4), 487-502.

Anwar, N. P., \& Bhutta, S. M. (2014). Student's Attitude Towards Science in Lower Secondary Classes: Comparison Across Regions. Journal of Educational Research, 17(1), 77-90. 
Budur, T. L. (2013). Integration of Character Education through Inquiry with Lesson Study in Biology Learning to Improve the Scientific Attitude of Class VII Students of SMPN 1 Singosari. Journal of Science Education, 1(2). 171-177.

Coal, H. H. (2016). Methods and models of the integration of science and Islam in Islamic Higher Education. Retrieved from https://www.researchgate. net/publications/324744404.

Iryani, E. (2017). Quran and science. Scientific Journal of Batanghari University Jambi, 17(3). 66-83.

Jamila. (2016). Islamic-based education that is self-sufficient and mature. Journal of EduTech, 2(2), 73-83.

Jamilah, J., Najib, A. A., Dzulkhairi, M., Ariff, H., \& Ismail, N. N. (2014). Integration of Islamic input in medical curriculum-Universiti Sains Islam Malaysia (USIM). The International Medical Journal of Malaysia, 13(2), 73-77.

Jelen, T. G., \& Lockett, L. A. (2014). Religion, Partisanship, and Attitudes Toward Science Policy. SAGEOpen, 4(1). Retrieved from http://doi. org/10.1177/2158244013518932.

Language Development and Cultivation Agency. (2016). KBBI online. Jakarta: Ministry of Education and Culture of the Republic of Indonesia.

Lestari, P. (2016). Scientific Attitude of Class XI Science 1 SMAN 3 Bengkulu Tengah Students in Biology Learning with an Inquiry Approach. Bengkulu: Bengkulu University

Lubis, M. (2011). Value Education Evaluation. Student Library.

Madjid, A. (2014). God-Based Education: Building Character Humans. Ghalia Indonesia

Marvavilha, A., \& Suparlan, S. (2018). Model of integration of Islamic values in science learning. Humanika: Scientific Studies of General Courses, 18(1). 59-80.

Maulana, M. R. (2015). Value Clarification Approach on the Concept of Change and Environmental Pollution to Grow Students' Concern for the Environment Around Class X at SMA NU Lemahabang. [Essay]. IAIN Sheikh Nurjati Cirebon.

Mawardi, I. (2012). Life Skills Education Based on Islamic Values in Learning. Nadwa (Journal of Islamic Education), 6(2), 216-234.

Nurasni, N., Darmawati, D., \& Yustini, Y. (2015). Students' Perception of Class X2 MA Darul Hikmah Pekanbaru Toward Iqro Learning Model Implementation in Biology Subject Academic Year 2014/2015. Biology Education Studies Program, The Faculty of Education and Teacher Training, University of Riau, 1-15.

Ogunbado, A. F., \& Al-Otaibi, A. M. (2013). Is quality management an Islamic value? IOSR Journal of Business and Management, 8(3), 6-13.

Prasetyo, Z. K. (2013). Local Wisdom-Based Science Learning. National Seminar on Physics and Physics Education 2013. FKIP: Sebelas Maret University.

Rahman, M. T. (2011). Integrating Lessons from the Qur'an and Hadith in teaching molecular biology. Revelation and Science Journal, 1(03), 75-84.

Sidik. (2016). Journal of Integrated Teaching Materials with Religious Values in the Human Digestive System as an Effort to Improve Attitudes and Concept Mastery of High School Students. Bandung: Indonesian University of Education.

Sukmadinata. (2017). Educational research methods. Rosdakarya.

Sugiyono. (2012). Educational research methods: quantitative, qualitative and $\mathrm{R} \& \mathrm{D}$ approaches. Alfabeta.

Suryaningsih, Y. (2018). Application of Al-qur'an-Based Biology Learning as a Method for Character Building Students. Journal of Bio Educatio, 3(1), 22-33.

Susilowati, S. (2017). Development of science teaching materials integrated with Islamic values to improve science learning outcomes. Journal of Science Education Innovation, 3(1), 78-88.

Ulfa, S, W. (2016). Practicum-Based Learning: Efforts to Develop Students' Scientific Attitude in Biology Learning. Nizhamiyah Journal, 6(1), 65-77. 
Utami T, A. (2014). Implementation of Religious Values in Character Education at SMA Negeri Kutowinangun Kebumen. [On line]. Available at (http:// Repository_uny.ac.id). Accessed January 22, 2019.

Zain, Z \& Vebrianto, R. (2017). Integration of Science and Islam in the Learning Process of the Science Clump. National Seminar on Information Technology, Communication and Industry (STNKI). Faculty of Science and Technology Uin Sultan Syarif Kasim Riau. Pekanbaru. 703708 